\title{
LIBERTAD DE CIRCULACION, ASILO Y REFUGIO EN LA UNION EUROPEA.
}

(Dira.)

REIG FABADO, I.

- Editorial: TIRANT LO BLANCH

- ISBN: 9788490535288

- Páginas: 422

- Fecha de la edición: 7/02/2014

En un contexto de crisis económica global, la libre circulación de personas, uno de los principios básicos en la construcción interna de la actual Unión Europea, presenta fisuras. Asimismo, la regulación europea de los flujos migratorios ha experimentado severas restricciones. Bajo estas circunstancias, conviene debatir sobre la política migratoria europea presente y futura. Y ello bajo una perspectiva integral que abarca tanto supuestos intracomunitarios que vulneran la libre circulación de personas en la Unión Europea, como extracomunitarios que restringen la aplicación de normativa internacional de ius cogens. Todo ello en un marco que reclama la reforma del sistema Schengen. En definitiva, esta obra plantea la necesidad de hacer valer los principios europeos e internacionales en la política migratoria europea, reivindicando la tradición garantista europea en materia de derechos civiles. 